\title{
Bidentate N-heterocyclic carbene complexes of Group 13 trihydrides and trihalides
}

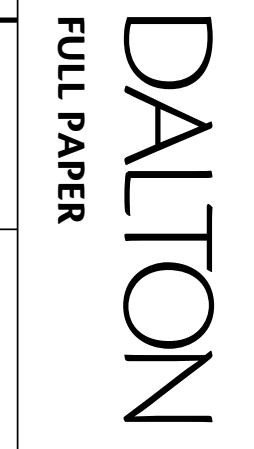

\author{
Robert J. Baker, ${ }^{a}$ Marcus L. Cole, ${ }^{a}$ Cameron Jones ${ }^{* a}$ and Mary F. Mahon ${ }^{b}$ \\ ${ }^{a}$ Department of Chemistry, University of Wales, Cardiff, P. O. Box 912, Park Place, Cardiff, \\ UK CF10 $3 T B$ \\ ${ }^{b}$ Department of Chemistry, University of Bath, Bath, UK BA2 7 AY
}

Received 14th January 2002, Accepted 8th March 2002

First published as an Advance Article on the web 5th April 2002

Treatment of the potentially chelating bis-carbene, 1,2-ethylene-3,3'-di-tert-butyl-diimidazole-2,2' -diylidene, EtIBu $\mathrm{t}^{\mathrm{t}}$ with $\left[\mathrm{MH}_{3}\left(\mathrm{NMe}_{3}\right)\right], \mathrm{M}=\mathrm{Al}, \mathrm{Ga}$, In, in a $1: 1$ or $1: 2$ stoichiometery led to good yields of the metal rich $2: 1$ adducts, $\left[\left(\mathrm{MH}_{3}\right)_{2}(\mu\right.$-EtIBut $\left.)\right]$. These complexes have been spectroscopically characterised and the X-ray crystal structures of two $(\mathrm{M}=\mathrm{Al}$ or $\mathrm{In})$ obtained. In contrast, the $1: 1$ or $1: 2$ reactions of $\mathrm{EtIBu}^{\mathrm{t}}$ with $\mathrm{MX}_{3}, \mathrm{M}=\mathrm{In}$ or $\mathrm{Tl}, \mathrm{X}=\mathrm{Br}$ or $\mathrm{Cl}$, led to the $1: 1$ adducts, $\left[\mathrm{MX}_{3}\left(\mathrm{EtIBu}^{t}\right)\right]$. The X-ray crystal structure of one of these, $\left[\operatorname{InBr}_{3}\left(\mathrm{EtIBu}^{\mathrm{t}}\right)\right]$, shows the ligand to act in a chelating mode, taking up equatorial positions of an trigonal bipyramid. The reactions of $\mathrm{EtIBu}^{\mathrm{t}}$ with $\mathrm{MCl}_{3}, \mathrm{M}=\mathrm{Al}$ or $\mathrm{Ga}$, led to decomposition and in the aluminium reaction the major product of the decomposition process was the bis-imidazolium salt, $\left[\mathrm{EtIBu}^{t} \mathrm{H}_{2}\right][\mathrm{Cl}]_{2}$, which has also been crystallographically characterised. Several related reactions are described.

\section{Introduction}

Since the isolation of the first room temperature stable N-heterocyclic carbene (NHC) in 1991 these compounds have been widely utilised in the synthesis of transition metal complexes, ${ }^{1}$ many of which have been found to be catalytically active. $^{2}$ Their activity in this respect has been explained by the now recognised close analogy between NHCs and nucleophilic tertiary phosphine ligands. ${ }^{3}$ This analogy has also been exploited in the synthesis of an ever growing number of unusually stable main group metal-carbene complexes. ${ }^{4}$ In this arena we have utilised the stabilising properties of monodentate NHCs in the preparation of a series of indium and thallium halide complexes, $\mathbf{1}$ and $\mathbf{2},^{5-7}$ but also in the synthesis of remarkably stable Group 13 hydride complexes. Most significant of these are the first indium trihydride complexes, $\mathbf{3}^{\mathbf{8}}$ and $4,{ }^{6}$ the latter of which does not decompose until $115^{\circ} \mathrm{C}$ in the solid state and whose chemistry we are systematically studying. It is noteworthy that as part of a broader study we have prepared a range of tertiary phosphine and amine complexes of $\mathrm{InH}_{3}$, e.g. $\left[\mathrm{InH}_{3}\left(\mathrm{PCy}_{3}\right)\right], \mathrm{Cy}=$ cyclohexyl, and compared their chemistry to that of compounds such as 3 and $4 .^{9}$

We wished to extend our studies in this area by exploring the interaction of a bidentate carbene, viz. 1,2-ethylene-3,3'-di-tertbutyl-diimidazole-2,2'-diylidene, EtIBu ${ }^{\mathrm{t}}$, with Group 13 trihydrides and trihalides. The reason for this was that $\mathrm{EtIBu}^{\mathrm{t}}$ has been shown to behave similarly to bis-phosphine ligands in that it can act in a chelating mode when complexed to transition metal fragments. ${ }^{3 a, 10}$ We were intrigued to see if carbene chelation would occur in Group 13 complexes. In the case of aluminium and gallium trihydrides only the bridging mode has previously been observed in related monomeric or polymeric bis-phosphine complexes, e.g. $\left[\left(\mathrm{MH}_{3}\right)_{2}\left\{\mu-\left(\mathrm{Pr}^{\mathrm{i}}\right)_{2} \mathrm{PCH}_{2} \mathrm{CH}_{2}-\right.\right.$ $\left.\left.\mathrm{P}\left(\mathrm{Pr}^{\mathrm{i}}\right)_{2}\right\}\right], \mathrm{M}=\mathrm{Al}$ or $\mathrm{Ga},\left[\left\{\left(\mathrm{AlH}_{3}\right)\left[\mu-\left(\mathrm{Pr}^{\mathrm{i}}\right)_{2} \mathrm{PCH}_{2} \mathrm{CH}_{2} \mathrm{P}\left(\mathrm{Pr}^{\mathrm{i}}\right)_{2}\right]\right\}_{\infty}\right] .{ }^{11}$ If, however, EtIBu ${ }^{\mathrm{t}}$ could chelate $\mathrm{MH}_{3}$ fragments, the possibility of forming ionic complexes, e.g. $\left[\mathrm{MH}_{2}\left(\mathrm{EtIBu}^{\mathrm{t}}\right)\right]\left[\mathrm{MH}_{4}\right]$, would exist, especially considering the fact that the $\mathrm{AlH}_{3}$ fragment is known to form similar, very thermally stable ionic com- plexes, e.g. $\left[\mathrm{AlH}_{2}(\mathrm{~L})\right]\left[\mathrm{AlH}_{4}\right]$, in combination with polydentate donors, $\mathrm{L}=$ pmdeta or tetramethylcyclam. ${ }^{12}$ The results of our endeavours in this area are reported herein.

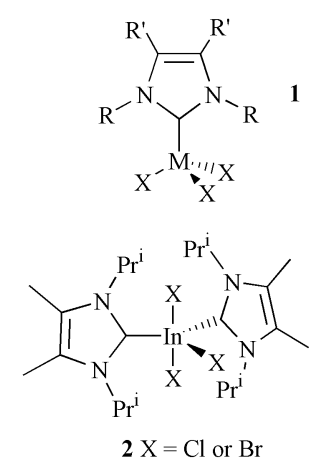

$$
\begin{aligned}
& \mathrm{M}=\text { In } \mathrm{X}=\mathrm{Cl} \mathrm{R}=\operatorname{Pr}^{\mathrm{i}} \mathrm{R}^{\prime}=\mathrm{Me} \\
& \mathrm{Br} \quad \operatorname{Pr}^{\mathrm{i}} \mathrm{Me} \\
& \mathrm{Cl} \text { mesityl } \mathrm{H} \\
& \mathrm{M}=\mathrm{Tl} \mathrm{X}=\mathrm{Cl} \mathrm{R}=\text { mesityl } \quad \mathrm{R}^{\prime}=\mathrm{H} \\
& \begin{array}{lll}
\mathrm{Br} & \text { mesityl } & \mathrm{H} \\
\mathrm{Cl} & \text { mesityl } & \mathrm{Br}
\end{array}
\end{aligned}
$$<smiles>[R]C=C([R])C</smiles><smiles>[Y5]C1N([R])C(C)=C(C)N1[R]</smiles>$$
\mathrm{H}^{-\operatorname{In}} \stackrel{\ln }{\mathrm{H}} \mathrm{H}
$$$$
3 \mathrm{R}=\mathrm{Pr}^{\mathrm{i}} \quad \mathrm{R}^{\prime}=\mathrm{Me}
$$$$
4 \mathrm{R}=\text { mesityl } \mathrm{R}^{\prime}=\mathrm{H}
$$

\section{Results and discussion}

\section{Group 13 trihydride complexes}

Treatment of EtIBu ${ }^{\mathrm{t}}$ with two equivalents of $\left[\mathrm{MH}_{3}\left(\mathrm{NMe}_{3}\right)\right]$, $\mathrm{M}=\mathrm{Al}, \mathrm{Ga}$, In, in either diethyl ether or toluene at low temperature led to the precipitation of 5-7 in good yields upon warming to room temperature (Scheme 1). These compounds were only sparingly soluble in most common solvents but could be recrystallised from large volumes of diethyl ether or toluene. Interestingly, when the reactions were carried out in a $1: 1$ stoichiometry the same products resulted and the unreacted $\mathrm{EtIBu}^{\mathrm{t}}$ could be recovered. In addition, 7 has been prepared in good yield via the reaction of $\mathrm{EtIBu}^{\mathrm{t}}$ with two equivalents of $\mathrm{LinH}_{4}$ with a concomitant elimination of $\mathrm{LiH}$, in a similar fashion to the preparation of $\mathbf{4}^{6}$

The fact that only the "alane rich" $2: 1$ complex, 5, was formed under any stoichiometry of reactants is of interest as related bis-phosphine ligands nearly always form polymeric 
<smiles></smiles>

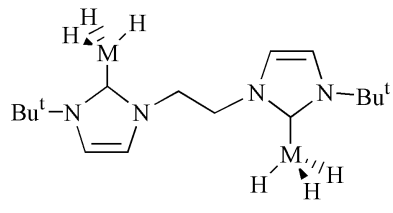

$\mathrm{M}=\mathrm{Al}$ 5, Ga 6, In 7

Scheme 1 Reagents and conditions: i, $\mathrm{MH}_{3}\left(\mathrm{NMe}_{3}\right),-\mathrm{NMe}_{3} ; \mathrm{ii}, \mathrm{LiInH}_{4}$ $-\mathrm{LiH}$

$1: 1$ complexes with alane due to the preference for the aluminium centre of the $\mathrm{AlH}_{3}$ fragment to attain a coordination number of five or above. ${ }^{11}$ The "indane rich" compound, 7, is even more surprising given our recent observation that the indane fragment has an even greater tendency toward hypervalent structures than alane. ${ }^{9 a}$ Compound $\mathbf{6}$, however, was expected as the greater electronegativity of gallium relative to $\mathrm{Al}$ or In has meant that the $\mathrm{GaH}_{3}$ fragment generally will not attain a coordination number greater than four, even in the presence of bis-phosphine ligands. These observations can be explained by the highly nucleophilic nature of the carbene ligands in these complexes, which apparently electronically satisfy the metal centres. Evidence for this proposal comes from the fact that treating 5 or 7 with an excess of EtIBu ${ }^{t}$ led to no reaction. In addition, treating 7 with an excess of $\mathrm{PEt}_{3}$ at $-10{ }^{\circ} \mathrm{C}$ in diethyl ether did not lead to the formation of the five-coordinate complex, $\left[\left\{\left(\mathrm{Et}_{3} \mathrm{P}\right) \mathrm{InH}_{3}\right\}_{2}\left(\mu-\mathrm{EtIBu}^{\mathrm{t}}\right)\right]$ but instead to rapid decomposition to indium metal, $\mathrm{PEt}_{3}$ and free EtIBu$u^{\mathrm{t}}$. The cause of this decomposition is presumed to be a ligand substitution reaction leading to $\left[\mathrm{InH}_{3}\left(\mathrm{PEt}_{3}\right)\right]$ which is known to rapidly decompose above $-30{ }^{\circ} \mathrm{C} .{ }^{9 a}$

Both compounds 5 and $\mathbf{6}$ proved to be moderately thermally stable (dec. $122-124{ }^{\circ} \mathrm{C}$ and $168-171{ }^{\circ} \mathrm{C}$ ) but less so than other carbene-alane or gallane complexes. If a comparison is drawn with the thermally stable indane complex, $4\left(\mathrm{dec} .115^{\circ} \mathrm{C}\right)$, complex 7 is disappointingly thermally frail (dec. $10-12{ }^{\circ} \mathrm{C}$ ). In addition, when its decomposition is followed by ${ }^{1} \mathrm{H}$ NMR in toluene, it deposits indium metal above $-15^{\circ} \mathrm{C}$ and a multitude of resonances appear which are indicative of $\mathrm{EtIBu}^{\mathrm{t}}$ ligand decomposition, possibly via ring opening of the imidazole heterocycles. This contrasts with $\mathbf{4}$ which decomposes in toluene to give indium metal, $\mathrm{H}_{2}$ gas and regenerates the free carbene intact. ${ }^{6}$

The spectroscopic data for 5-7 are consistent with their proposed formulations. Their ${ }^{1} \mathrm{H}$ NMR spectra display the expected resonances for the carbene ligand and in the cases of 6 and 7 broad resonances were observed at $4.61 \mathrm{ppm}$ and $6.06 \mathrm{ppm}$ respectively, each of which integrates for six hydride ligands. The resonance for the hydride ligands of $\mathbf{5}$ was too broad to be observed, probably because of the quadrupolar nature of the aluminium centre to which they are attached. It proved impossible to obtain meaningful ${ }^{13} \mathrm{C}$ NMR data for $\mathbf{6}$ and 7 due to their very low solubility in all common solvents. The IR spectra (Nujol mulls) of 5-7 displayed strong, broad characteristic M-H stretches centred at 1757, 1804 and 1643 $\mathrm{cm}^{-1}$ respectively. A very similar pattern has been observed for the monodentate carbene- $\mathrm{MH}_{3}$ complexes, $\left[\mathrm{MH}_{3}\left\{\mathrm{CN}\left(\mathrm{Pr}^{\mathrm{i}}\right) \mathrm{C}_{2}-\right.\right.$ $\left.\left.\mathrm{Me}_{2} \mathrm{~N}\left(\mathrm{Pr}^{\mathrm{i}}\right)\right\}\right] \mathrm{M}=\mathrm{Al} 1730 \mathrm{~cm}^{-1}, \mathrm{Ga} 1775 \mathrm{~cm}^{-1}$, In $1640 \mathrm{~cm}^{-1} ; 8$ which reflects the strength of the $\mathrm{M}-\mathrm{H}$ bonds involved. It is worth noting that no structure is normally seen in the $\mathrm{M}-\mathrm{H}$ stretching bands of Group 13 trihydride complexes which can be greater than $200 \mathrm{~cm}^{-1}$ wide. This is indeed the case for 7 but interestingly three broad overlapping absorptions can be detected in the spectra of $\mathbf{5}$ and $\mathbf{6}$. These have not been specifically assigned and attempts to obtain solution IR data failed due to the low solubility of both complexes.

The X-ray crystal structures of $\mathbf{5}$ and $\mathbf{7}$ were obtained (Figs. 1 and 2, Table 1) though 6 could only be obtained as a micro-

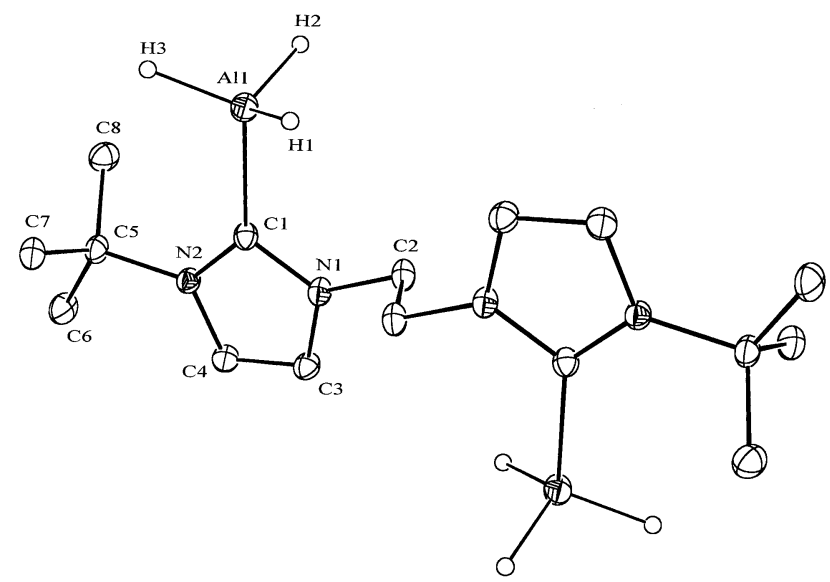

Fig. 1 Molecular structure of compound 5. Selected bond lengths $(\AA)$ and angles $\left({ }^{\circ}\right): \mathrm{Al}(1)-\mathrm{C}(1) 2.067(2), \mathrm{Al}(1)-\mathrm{H}(1)$ 1.52(3), $\mathrm{Al}(1)-\mathrm{H}(2)$ 1.52(3), $\mathrm{Al}(1)-\mathrm{H}(3)$ 1.47(3), N(1)-C(1) 1.362(3), N(1)-C(2) 1.463(3), $\mathrm{N}(2)-\mathrm{C}(4)$ 1.383(3), $\mathrm{N}(2)-\mathrm{C}(1) 1.357(3), \mathrm{N}(1)-\mathrm{C}(3)$ 1.375(3), C(3)-C(4) 1.345(3), $\mathrm{N}(2)-\mathrm{C}(1)-\mathrm{N}(1)$ 104.21(18), $\mathrm{C}(1)-\mathrm{Al}(1)-\mathrm{H}(1)$ 105.0(12), $\mathrm{C}(1)-$ $\mathrm{Al}(1)-\mathrm{H}(2) \quad 107.7(12), \mathrm{C}(1)-\mathrm{Al}(1)-\mathrm{H}(3) \quad 112.1(11), \mathrm{H}(1)-\mathrm{Al}(1)-\mathrm{H}(2)$ 112.4(17), $\mathrm{H}(1)-\mathrm{Al}(1)-\mathrm{H}(3)$ 110.2(16), H(2)-Al(1)-H(3) 109.3(16)

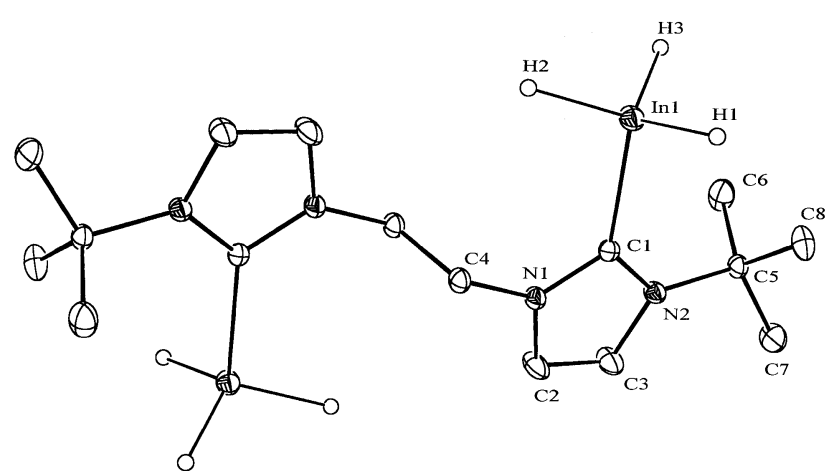

Fig. 2 Molecular structure of compound 7. Selected bond lengths $(\AA)$ and angles $\left(^{\circ}\right)$ : $\operatorname{In}(1)-\mathrm{C}(1) 2.3069(16), \mathrm{N}(1)-\mathrm{C}(1) 1.355(2), \mathrm{N}(1)-\mathrm{C}(2)$ $1.376(2), \mathrm{N}(2)-\mathrm{C}(1) 1.362(2), \mathrm{N}(2)-\mathrm{C}(3) 1.384(2), \mathrm{C}(2)-\mathrm{C}(3) 1.346(3)$, $\operatorname{In}(1)-\mathrm{H}(1)$ 1.73(2), $\operatorname{In}(1)-\mathrm{H}(2)$ 1.73(2), $\mathrm{In}(1)-\mathrm{H}(3)$ 1.73(2), N(1)-C(1)$\mathrm{N}(2) 104.58(14), \mathrm{C}(1)-\operatorname{In}(1)-\mathrm{H}(1)$ 105.7(11), C(1)-In(1)-H(2) 106.1(9), $\mathrm{C}(1)-\mathrm{In}(1)-\mathrm{H}(3)$ 105.3(9), H(1)-In(1)-H(2) 113.0(15), H(1)-In(1)-H(3) $115.0(15), \mathrm{H}(2)-\operatorname{In}(1)-\mathrm{H}(3) 110.9(13)$.

crystalline solid. The two structurally characterised compounds are isostructural but not isomorphous. They are centrosymmetric monomers and show the EtIBu ${ }^{\mathrm{t}}$ ligand bridging two $\mathrm{MH}_{3}$ fragments in a similar fashion to that described for the alane rich bis-phosphine complex, $\left[\left(\mathrm{AlH}_{3}\right)_{2}\left\{\mu-\left(\mathrm{Pr}^{\mathrm{i}}\right)_{2} \mathrm{PCH}_{2} \mathrm{CH}_{2}-\right.\right.$ $\left.\left.\mathrm{P}\left(\operatorname{Pr}^{\mathrm{i}}\right)_{2}\right\}\right] .{ }^{11}$ The hydride ligands of both complexes were located from difference maps and refined isotropically. The average In-H distance in $7(1.73 \AA)$ compares well to the mean of all structurally characterised terminal $\mathrm{In}-\mathrm{H}$ bond lengths $(1.70 \AA) .{ }^{13}$ In contrast the average $\mathrm{Al}-\mathrm{H}$ distance in $\mathbf{5}(1.50 \AA)$ is close to that in $\left[\mathrm{AlH}_{3}\left\{\mathrm{CN}\left(\mathrm{Pr}^{\mathrm{i}}\right) \mathrm{C}_{2} \mathrm{Me}_{2} \mathrm{~N}\left(\mathrm{Pr}^{\mathrm{i}}\right)\right\}\right](1.52 \AA)^{8 b}$ but shorter than the mean for all structurally characterised $\mathrm{Al}-\mathrm{H}$ bonds $(1.61 \AA) .{ }^{13}$ This difference is not significant given the errors involved in these bond lengths. Notwithstanding the inherant problems that the refinement of hydrogen atom positions using X-ray data pose, the broad indications are that the geometry about the metal centre in $\mathbf{5}$ is close to tetrahedral (av. $\mathrm{C}-\mathrm{Al}-\mathrm{H} 108.2^{\circ}$, av. $\mathrm{H}-\mathrm{Al}-\mathrm{H} 110.6^{\circ}$ ) whilst in 7 it is slightly flattened tetrahedral (av. C-In-H $105.7^{\circ}$, av. $\mathrm{H}-\mathrm{In}-\mathrm{H} 113.0^{\circ}$ ). 
Table 1 Crystal data for compounds 5, 7, 9.2 $\mathrm{CH}_{2} \mathrm{Cl}_{2}$ and $\mathbf{1 1} \cdot \mathrm{CH}_{2} \mathrm{Cl}_{2}$

\begin{tabular}{|c|c|c|c|c|}
\hline & 5 & 7 & 9. $2 \mathrm{CH}_{2} \mathrm{Cl}_{2}$ & $11 \cdot \mathrm{CH}_{2} \mathrm{Cl}_{2}$ \\
\hline $\begin{array}{l}\text { Chemical formula } \\
\text { FW }\end{array}$ & $\begin{array}{l}\mathrm{C}_{16} \mathrm{H}_{32} \mathrm{Al}_{2} \mathrm{~N}_{4} \\
334.42\end{array}$ & $\begin{array}{l}\mathrm{C}_{16} \mathrm{H}_{32} \mathrm{In}_{2} \mathrm{~N}_{4} \\
510.10\end{array}$ & $\begin{array}{l}\mathrm{C}_{18} \mathrm{H}_{30} \mathrm{Br}_{3} \mathrm{Cl}_{4} \mathrm{InN}_{4} \\
798.81\end{array}$ & $\begin{array}{l}\mathrm{C}_{17} \mathrm{H}_{30} \mathrm{Cl}_{4} \mathrm{~N}_{4} \\
432.25\end{array}$ \\
\hline Crystal system & Monoclinic & Triclinic & Monoclinic & Orthorhombic \\
\hline Space group & $P 2_{1} / n$ & $P \overline{1}$ & $P 2_{1} / n$ & $C 2 / c$ \\
\hline a/Å & $6.0020(2)$ & $5.6110(1)$ & $12.0470(3)$ & 13.401(3) \\
\hline$b / \AA ̊$ & $25.0350(8)$ & $8.2530(2)$ & $14.3610(3)$ & $15.748(3)$ \\
\hline$c / \AA ̊$ & $6.8670(2)$ & $11.6770(3)$ & $16.8110(4)$ & $11.461(2)$ \\
\hline$a l^{\circ}$ & 90 & $85.4570(10)$ & 90 & 90 \\
\hline$\beta /^{\circ}$ & $100.031(2)$ & $85.4100(10)$ & $105.887(1)$ & 90 \\
\hline$\gamma /{ }^{\circ}$ & 90 & $76.2580(10)$ & 90 & 90 \\
\hline$V / \AA^{3}$ & $1016.06(6)$ & $522.56(2)$ & $2797.33(11)$ & $2281.4(8)$ \\
\hline$Z$ & 2 & 1 & 4 & 4 \\
\hline$T / \mathrm{K}$ & $150(2)$ & $150(2)$ & $150(2)$ & $150(2)$ \\
\hline$\mu\left(\mathrm{Mo}-\mathrm{K}_{\alpha}\right) / \mathrm{mm}^{-1}$ & 0.15 & 2.21 & 5.53 & 0.53 \\
\hline Reflections collected & 13427 & 13602 & 32746 & 14903 \\
\hline Unique reflections $/ R_{\text {int }}$ & $2391(0.0871)$ & $5444(0.0446)$ & $6384(0.0721)$ & $2244(0.0395)$ \\
\hline$R 1(I>2 \sigma(I))$ & 0.0533 & 0.0294 & 0.0475 & 0.0311 \\
\hline $\mathrm{w} R^{\prime} 2$ (all data) & 0.1431 & 0.0689 & 0.1187 & 0.0771 \\
\hline
\end{tabular}

These geometries can be compared to the coordination environment of the indium centre in $\left[\mathrm{InH}_{3}\left(\mathrm{PCy}_{3}\right)\right]$ which is much more flattened [av. P-In-H 101.4 ${ }^{\circ}$. av. $\mathrm{H}-\mathrm{In}-\mathrm{H} 116.2^{\circ}$ ]. This observation is in line with the greater nucleophilicity of NHCs relative to tertiary phosphines and explains why $\mathrm{AlH}_{3}$ and $\mathrm{InH}_{3}$ will not form five-coordinate complexes with NHCs whilst they both readily do so with tertiary phosphines. Finally, the $\mathrm{C}-\mathrm{M}$ bond lengths and $\mathrm{NCN}$ angles in $\mathbf{5}$ and $\mathbf{7}$ are in the normal region for carbene-Group 13 metal trihydride complexes. $^{8 b}$

It was thought worthy to investigate the reaction of a bulky bis-phosphine, $\mathrm{Cy}_{2} \mathrm{PCH}_{2} \mathrm{CH}_{2} \mathrm{PCy}_{2}$, with $\left[\mathrm{InH}_{3}\left(\mathrm{NMe}_{3}\right)\right]$ for purposes of comparison. When this reaction was carried out under either a $1: 1$ or $1: 2$ stoichiometry the polymeric compound, $\left[\left\{\left(\mathrm{InH}_{3}\right)\left(\mathrm{Cy}_{2} \mathrm{PCH}_{2} \mathrm{CH}_{2} \mathrm{PCy}_{2}\right)\right\}_{\infty}\right] \mathbf{8}$, precipitated from the reaction mixture in high yield. This result suggests that indane will not form a metal rich $2: 1$ adduct with this phosphine as it does with $\mathrm{EtIBu}^{\mathrm{t}}$, presumably because of the lower nucleophilicity of the phosphine ligand. Moreover, it again confirms the preference for hypervalency of the $\mathrm{InH}_{3}$ fragment over the $\mathrm{AlH}_{3}$ fragment as the latter does form an alane rich complex, $\left[\left(\mathrm{AlH}_{3}\right)_{2}\left(\mathrm{Cy}_{2} \mathrm{PCH}_{2} \mathrm{CH}_{2} \mathrm{PCy}\right)\right]$, with this ligand. ${ }^{11}$

Although $\mathbf{8}$ has low solubility in diethyl ether it is sufficiently soluble in toluene to allow NMR data to be obtained. These are consistent with its $1: 1$ formulation and its ${ }^{1} \mathrm{H}$ NMR spectrum displays a broad peak at $5.76 \mathrm{ppm}$ which was assigned to the three hydride ligands. Their presence was confirmed by the IR spectrum of the complex which shows a very strong, broad absorption centred at $1657 \mathrm{~cm}^{-1}$ which is in the normal In-H stretching region for indane complexes. ${ }^{14}$ Finally, the complex exhibits reasonable thermal stability in that it decomposes at $18-20{ }^{\circ} \mathrm{C}\left(\right.$ cf. $50{ }^{\circ} \mathrm{C}$ for $\left.\left[\mathrm{InH}_{3}\left(\mathrm{PCy}_{3}\right)\right]\right)$ giving an indium mirror and the free phosphine ligand.

\section{Group 13 trihalide complexes}

We have previously shown that monodentate NHCs can form five-coordinate complexes with indium trihalides, $\mathbf{2}$, in which the two carbene ligands take up equatorial positions of a trigonal bipyramidal coordination environment. ${ }^{5}$ This suggests that the $\mathrm{InX}_{3}, \mathrm{X}=\mathrm{Cl}$ or $\mathrm{Br}$, fragments are stronger Lewis acids than $\mathrm{InH}_{3}$ which only forms four-coordinate complexes with carbenes. We wished to explore the interaction of $\mathrm{EtIBu}^{\mathrm{t}}$ with a range of Group 13 halides to investigate any differences there may be between the resulting complexes and 5-7.

Accordingly, treatment of THF solutions of either $\mathrm{InBr}_{3}$ or $\mathrm{TlCl}_{3}$ with equimolar amounts of $\mathrm{EtIBu} u^{\mathrm{t}}$ resulted in the quantitative precipitation of the $1: 1$ adducts 9 and $\mathbf{1 0}$ (Scheme 2). Both compounds were sparingly soluble in dichloromethane but only $\mathbf{9}$ could be recrystallised from large volumes of this

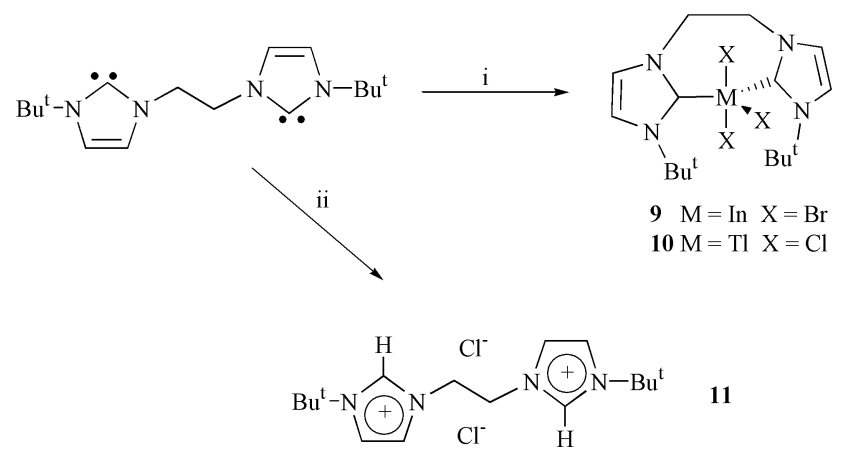

Scheme 2 Reagents and conditions: i, $\mathrm{MX}_{3}, \mathrm{THF}$; ii, $\mathrm{AlCl}_{3}, \mathrm{Et}_{2} \mathrm{O}$.

solvent. The reactions of $\mathrm{InBr}_{3}$ or $\mathrm{TlCl}_{3}$ with 0.5 equivalents of $\mathrm{EtIBu}^{\mathrm{t}}$ also yielded $\mathbf{9}$ and $\mathbf{1 0}$ as the only products, which shows these are favourable to metal rich $2: 1$ adducts analogous to 5-7. This again gives evidence that $\mathrm{InBr}_{3}$ is a stronger Lewis acid than $\mathrm{InH}_{3}$. The ${ }^{1} \mathrm{H}$ and ${ }^{13} \mathrm{C}$ NMR spectra of 9 are consistent with its structure though the very low solubility of $\mathbf{1 0}$ in $\mathrm{CD}_{2} \mathrm{Cl}_{2}$ made it impossible to obtain a ${ }^{13} \mathrm{C}$ NMR spectrum on this compound. Indeed, its ${ }^{1} \mathrm{H}$ NMR spectrum was weak and unavoidable precipitation of the sample lead to considerable line broadening and a subsequent lack of resolution regarding the expected ${ }^{4} J_{\mathrm{TIH}}$ coupling at the 4,5-positions of the imidazol2-ylidene groups which we have observed in similar systems. ${ }^{7}$

The X-ray crystal structure of $\mathbf{9} \cdot 2 \mathrm{CH}_{2} \mathrm{Cl}_{2}$ (Fig. 3, Table 1) was obtained and this shows the molecule to be monomeric with the carbene ligating the indium centre in a chelating mode and taking up two equatorial sites of a distorted trigonal bipyramid in a similar fashion to that seen in the bis(carbene)-indium halide complexes, $2 .{ }^{5}$ It is worthy of note that the EtIBut ligand has previously been observed to act in a chelating mode in two square planar nickel complexes, $\left[\text { cis- } \mathrm{NiMe}_{2}\left(\mathrm{EtIBu}^{\mathrm{t}}\right)\right]^{3}$ and $[$ cis$\left.\mathrm{NiCl}\left(\mathrm{PMe}_{3}\right)\left(\mathrm{EtIBu}^{t}\right)\right]\left[\mathrm{BPh}_{4}\right] .^{10}$ Both the In-C and $\mathrm{In}-\mathrm{Br}$ bond lengths in 9 are unexceptional though the axial $\mathrm{In}-\mathrm{Br}$ bonds are significantly longer $(2.737 \AA$ av.) than the equatorial $\mathrm{In}-\mathrm{Br}$ bond [2.5367(7) $\AA$ ]. Obviously, it cannot be sure that 10 adopts the same coordination mode as 9 but this seems likely given the available spectroscopic evidence and the similar properties of the two compounds.

The $1: 1$ reactions of $\mathrm{AlCl}_{3}$ and $\mathrm{GaCl}_{3}$ with $\mathrm{EtIBu}^{\mathrm{t}}$ proved less successful and in the latter case led to numerous unidentified products. The former reaction did not yield a $1: 1$ adduct but instead gave a moderate yield of the bis-imidazolium dichloride, 11. It is not known how this forms but it presumably involves the aluminium analogue of $\mathbf{9}$ as an intermediate. We have previously noted that imidazolium salts can form in the reactions of carbenes with Group 13 halides when water is 


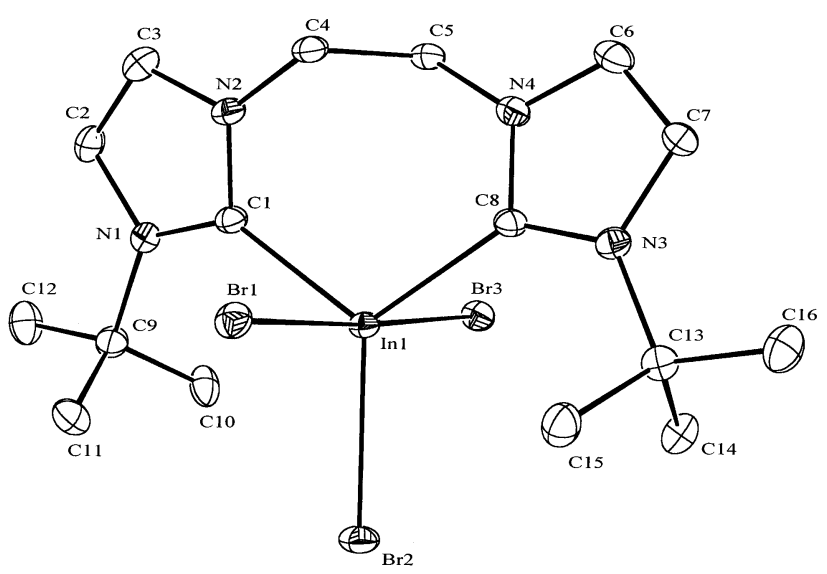

Fig. 3 Molecular structure of compound 9. Selected bond lengths $(\AA)$ and angles $\left({ }^{\circ}\right)$ : $\operatorname{In}(1)-C(8) 2.233(6), \operatorname{In}(1)-C(1) 2.236(6), \operatorname{In}(1)-\operatorname{Br}(2)$ 2.5367(7), $\operatorname{In}(1)-\operatorname{Br}(1)$ 2.7290(7), $\operatorname{In}(1)-\operatorname{Br}(3)$ 2.7449(7), N(1)-C(1) 1.357(8), $\mathrm{N}(2)-\mathrm{C}(1) 1.345(7), \mathrm{N}(3)-\mathrm{C}(8) 1.344(7), \mathrm{N}(4)-\mathrm{C}(8) 1.351(7)$ $\mathrm{N}(2)-\mathrm{C}(1)-\mathrm{N}(1)$ 105.2(5), N(3)-C(8)-N(4) 105.8(5), C(8)-In(1)-C(1) 112.5(2), $\mathrm{C}(8)-\operatorname{In}(1)-\operatorname{Br}(2) \quad 123.68(15), \quad \mathrm{C}(1)-\operatorname{In}(1)-\operatorname{Br}(2) \quad 123.86(15)$, C(8)-In(1)-Br(1) 92.98(15), C(1)-In(1)-Br(1) 85.46(15), Br(2)-In(1)$\operatorname{Br}(1)$ 91.04(2), C(8)-In(1)-Br(3) 84.71(15), C(1)-In(1)-Br(3) 92.97(15), $\operatorname{Br}(2)-\operatorname{In}(1)-\operatorname{Br}(3)$ 92.44(2), $\operatorname{Br}(1)-\operatorname{In}(1)-\operatorname{Br}(3)$ 176.50(2).

present. ${ }^{5,15}$ However, in this case efforts were made to rigorously exclude moisture and still $\mathbf{1 1}$ was formed in a moderate yield. Presumably, the acidic imidazolium protons originate from the solvent and the chloride from the $\mathrm{AlCl}_{3}$ fragment. The outcome of the aluminium in this reaction could not be determined.

The ${ }^{1} \mathrm{H}$ NMR spectrum of $\mathbf{1 1}$ displayed a resonance for the imidazolium protons at the 2-positions of the heterocycles and the carbon centres at the same positions resonate in the normal region for imidazolium salts. To confirm the nature of $\mathbf{1 1}$ its $\mathrm{X}$-ray crystal structure was obtained and found to include one molecule of dichloromethane of solvation for each molecule of the salt (Fig. 4, Table 1). The bond lengths and angles within the heterocycles suggest full delocalisation and all other geometrical parameters are unexceptional.

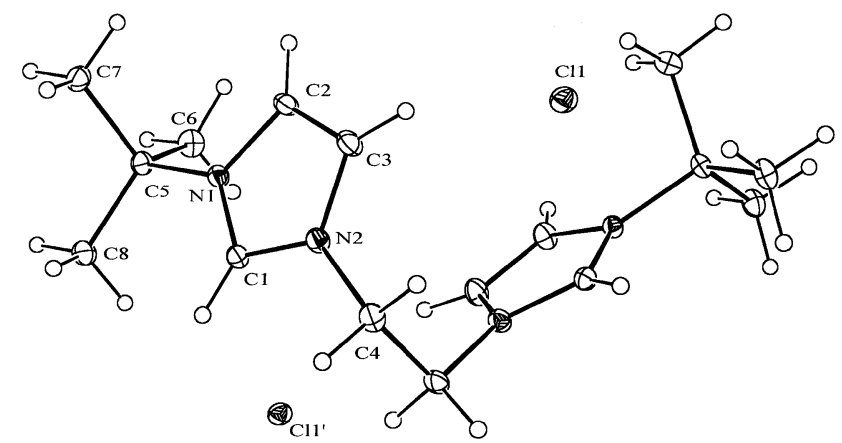

Fig. 4 Molecular structure of compound 11. Selected bond lengths $(\AA)$ and angles $\left({ }^{\circ}\right)$ : $\mathrm{N}(1)-\mathrm{C}(1) 1.3274(18), \mathrm{N}(1)-\mathrm{C}(2) 1.3862(18), \mathrm{N}(2)$ $\mathrm{C}(1) 1.3360(19), \mathrm{N}(2)-\mathrm{C}(3) 1.3804(19), \mathrm{C}(2)-\mathrm{C}(3) 1.345(2), \mathrm{N}(1)-\mathrm{C}(1)$ $\mathrm{N}(2) \quad 108.23(12), \quad \mathrm{C}(1)-\mathrm{N}(1)-\mathrm{C}(2) \quad 108.71(12), \quad \mathrm{C}(1)-\mathrm{N}(2)-\mathrm{C}(3)$ 108.88(12), C(3)-C(2)-N(1) 107.20(13), C(2)-C(3)-N(2) 106.98(12).

\section{Conclusions}

In summary, we have described the reactions of the bis-carbene ligand $\mathrm{EtIBu}^{\mathrm{t}}$ with a series of Group 13 trihydride and trihalide fragments. The results have shown that the $\mathrm{MH}_{3}$ fragments form only monomeric, four-coordinate metal rich complexes, $\left[\left(\mathrm{MH}_{3}\right)_{2}\left(\mu-\mathrm{EtIBu}^{\mathrm{t}}\right)\right]$, whereas $\mathrm{InBr}_{3}$ and $\mathrm{TlCl}_{3}$ form monomeric complexes in which the carbene ligand coordinates the metal in a chelating mode. The observed differences have been explained in terms of the relative Lewis acidities of the $\mathrm{MH}_{3}$ and $\mathrm{MX}_{3}, \mathrm{X}=$ halide, fragments. Work continues in our group on the stabilisation and application of $\mathrm{InH}_{3}$ and $\mathrm{TlH}_{3}$ complexes.

\section{Experimental}

\section{General}

All manipulations were carried out using standard Schlenk and glove box techniques under an atmosphere of high purity argon or dinitrogen. The solvents diethyl ether, toluene and THF were distilled over either potassium or $\mathrm{Na} / \mathrm{K}$ alloy then freeze/thaw degassed prior to use. $\mathrm{CH}_{2} \mathrm{Cl}_{2}$ was purified by distillation from $\mathrm{CaH}_{2}$ under a dinitrogen atmosphere. ${ }^{1} \mathrm{H},{ }^{13} \mathrm{C}$ and ${ }^{31} \mathrm{P}$ NMR spectra were recorded on Bruker DPX400 or Jeol Eclipse 300 spectrometers in deuterated solvents and were referenced to the residual ${ }^{1} \mathrm{H}$ resonances of the solvent used $\left({ }^{1} \mathrm{H} \mathrm{NMR}\right)$ or to external $85 \% \mathrm{H}_{3} \mathrm{PO}_{4}, 0.0 \mathrm{ppm}\left({ }^{31} \mathrm{P} \mathrm{NMR}\right)$. Mass spectra were recorded using a VG Fisons Platform II instrument under APCI conditions. Melting points were determined in sealed glass capillaries under argon, and are uncorrected. Reproducible microanalyses of 5-8 could not be obtained due to their thermal and/or extreme air sensitivity. Microanalyses on $\mathbf{9}$ and 11 could not be obtained as they readily lost dichloromethane of crystallisation over time. The starting materials EtIBu, ${ }^{\mathrm{t}}$ $\left[\mathrm{LiInH}_{4}\right]^{8}$ and $\left[\mathrm{MH}_{3}\left(\mathrm{NMe}_{3}\right)\right] \mathrm{M}=\mathrm{Al},{ }^{16} \mathrm{Ga}^{17}$ or In, ${ }^{8}$ were prepared by literature procedures. All other reagents were used as received.

$\left[\left(\mathrm{AlH}_{3}\right)_{2}(\boldsymbol{\mu}\right.$-EtIBut $\left.)\right] 5 . \mathrm{EtIBu}^{\mathrm{t}}(0.20 \mathrm{~g}, 0.73 \mathrm{mmol})$ in toluene $(55 \mathrm{ml})$ was added dropwise to a solution of $\left[\mathrm{AlH}_{3}\left(\mathrm{NMe}_{3}\right)\right]$ $(0.13 \mathrm{~g}, 1.46 \mathrm{mmol})$ in toluene $(35 \mathrm{ml})$ at $-50{ }^{\circ} \mathrm{C}$ over $15 \mathrm{~min}$. The resulting slurry was warmed to room temperature and stirred for $3 \mathrm{~h}$ whereupon volatiles were removed in vacuo. The residue was extracted with toluene $(50 \mathrm{ml})$, filtered and the filtrate placed at $-30{ }^{\circ} \mathrm{C}$ yielding colourless prisms of 5 overnight (0.18 g, 74\%). mp 122-124 ${ }^{\circ} \mathrm{C} \mathrm{dec} . ;{ }^{1} \mathrm{H}$ NMR (400 MHz, $\mathrm{C}_{6} \mathrm{D}_{6}$, $300 \mathrm{~K}) \delta 1.58\left(\mathrm{~s}, 18 \mathrm{H}, \mathrm{Bu}^{\mathrm{t}}\right), 4.53\left(\mathrm{~s}, 4 \mathrm{H}, \mathrm{CH}_{2}\right), 6.46(\mathrm{~s}, 2 \mathrm{H}, \mathrm{CH})$, $6.65(\mathrm{~s}, 2 \mathrm{H}, \mathrm{CH}) ;{ }^{13} \mathrm{C} \mathrm{NMR}\left(100.6 \mathrm{MHz}, \mathrm{C}_{6} \mathrm{D}_{6}, 300 \mathrm{~K}\right) \delta 31.7(\mathrm{~s}$, $\left.\mathrm{C}\left(\mathrm{CH}_{3}\right)_{3}\right), 46.7\left(\mathrm{~s}, \mathrm{CH}_{2}\right), 53.4\left(\mathrm{~s}, \mathrm{C}\left(\mathrm{CH}_{3}\right)_{3}\right), 115.9(\mathrm{~s}, \mathrm{CH}), 119.2$ (s, CH); MS APCI: $m / z(\%) 138\left[\left\{\mathrm{H}_{2} \mathrm{EtIBu}^{\mathrm{t}}\right\}^{2+}, 100\right], 303[\{\mathrm{M}-$ $\left.\left.\mathrm{AlH}_{4}\right\}^{+}, 35\right]$; IR (Nujol) $v / \mathrm{cm}^{-1} 1713$ (s br, Al-H str.), 1762 (s br, Al-H str.), 1797 (s br, Al-H str.).

$\left[\left(\mathrm{GaH}_{3}\right)_{2}(\boldsymbol{\mu}\right.$-EtIBut $\left.)\right]$ 6. EtIBu ${ }^{\mathrm{t}}(0.41 \mathrm{~g}, 1.52 \mathrm{mmol})$ in diethyl ether $(25 \mathrm{ml})$ was added dropwise to a solution of $\left[\mathrm{GaH}_{3}^{-}\right.$ $\left.\left(\mathrm{NMe}_{3}\right)\right](0.40 \mathrm{~g}, 3.04 \mathrm{mmol})$ in diethyl ether $(35 \mathrm{ml})$ at $-50{ }^{\circ} \mathrm{C}$ over $15 \mathrm{~min}$. The resulting slurry was warmed to room temperature and stirred overnight and the precipitate isolated by filtration. The residue was washed with diethyl ether $(2 \times 5 \mathrm{ml})$ and extracted with toluene $(50 \mathrm{ml})$. The extract was placed at $-30{ }^{\circ} \mathrm{C}$ yielding 6 as a colourless powder $(0.88 \mathrm{~g}, 59 \%) . \mathrm{mp}$ $168-171{ }^{\circ} \mathrm{C}$ dec.; ${ }^{1} \mathrm{H}$ NMR (400 MHz, $\left.\mathrm{C}_{6} \mathrm{D}_{6}, 300 \mathrm{~K}\right) \delta 1.20(\mathrm{~s}$, $\left.18 \mathrm{H}, \mathrm{Bu}^{\mathrm{t}}\right), 3.95\left(\mathrm{~s}, 4 \mathrm{H}, \mathrm{CH}_{2}\right), 4.61$ (br. s, $\left.6 \mathrm{H}, \mathrm{GaH}_{3}\right), 5.31(\mathrm{~s}, 2 \mathrm{H}$, $\mathrm{CH}), 5.35$ (s, 2H, CH); MS APCI: $m / z(\%) 138\left[\left\{\mathrm{H}_{2} \mathrm{EtIBu}^{\mathrm{t}}\right\}^{2+}\right.$, 100]; IR (Nujol) v/cm ${ }^{-1} 1849$ (s br, Ga-H str.), 1808 (s br, Ga-H str.), 1757 (s br, Ga-H str.).

$\left[\left(\mathrm{InH}_{3}\right)_{2}(\boldsymbol{\mu}-\mathbf{E t I B u})\right]$ 7. (i) $\operatorname{EtIBu}^{\mathrm{t}}(0.19 \mathrm{~g}, 0.69 \mathrm{mmol})$ in diethyl ether $(25 \mathrm{ml})$ was added dropwise to a solution of $\left[\mathrm{InH}_{3}\left(\mathrm{NMe}_{3}\right)\right]$ (ca. $\left.1.38 \mathrm{mmol}\right)$ in diethyl ether $(35 \mathrm{ml})$ at $-50{ }^{\circ} \mathrm{C}$ over $15 \mathrm{~min}$. The resulting slurry was warmed to $-30{ }^{\circ} \mathrm{C}$ and stirred for $3 \mathrm{~h}$ whereupon it was filtered. The filtrate was placed at $-30{ }^{\circ} \mathrm{C}$ yielding colourless rods of 7 overnight $(0.17$ g, 48\%). mp $10-12{ }^{\circ} \mathrm{C}$ dec. (ii) $\operatorname{EtIBu}^{\mathrm{t}}(0.15 \mathrm{~g}, 0.55 \mathrm{mmol})$ in diethyl ether $(20 \mathrm{ml})$ was added dropwise to a solution of $\mathrm{LiInH}_{4}(c a .1 .10 \mathrm{mmol})$ in diethyl ether $(35 \mathrm{ml})$ at $-78{ }^{\circ} \mathrm{C}$ over $15 \mathrm{~min}$. The resulting slurry was warmed to $-30^{\circ} \mathrm{C}$ and stirred for $3 \mathrm{~h}$ whereupon it was filtered. The filtrate was placed at $-30{ }^{\circ} \mathrm{C}$ yielding colourless rods of 7 overnight $(0.16 \mathrm{~g}, 58 \%)$. mp $10-12{ }^{\circ} \mathrm{C}$ dec. ${ }^{1} \mathrm{H}$ NMR $\left(300 \mathrm{MHz}, \mathrm{C}_{6} \mathrm{D}_{5} \mathrm{CD}_{3}, 223 \mathrm{~K}\right)$ $\delta 1.31\left(\mathrm{~s}, 18 \mathrm{H}, \mathrm{Bu}^{\mathrm{t}}\right), 4.53\left(\mathrm{~s}, 4 \mathrm{H}, \mathrm{CH}_{2}\right), 5.46(\mathrm{~s}, 2 \mathrm{H}, \mathrm{CH}), 6.06$ (br s, $6 \mathrm{H}, \mathrm{InH}_{3}$ ), 6.22 (s, 2H, CH); IR (Nujol) $v / \mathrm{cm}^{-1} 1643$ (s br, In-H str.). 
[ $\left.\left\{\left(\mathrm{InH}_{3}\right)\left(\mathrm{Cy}_{2} \mathbf{P C H} \mathbf{C H}_{2} \mathbf{P C y}\right)\right\}_{\infty}\right]$ 8. $\mathrm{Cy}_{2} \mathrm{PCH}_{2} \mathrm{CH}_{2} \mathrm{PCy}_{2}(1.07 \mathrm{~g}$, $2.53 \mathrm{mmol})$ in diethyl ether $(30 \mathrm{ml})$ was added dropwise to a solution of $\left[\mathrm{InH}_{3}\left(\mathrm{NMe}_{3}\right)\right]$ ( $c$ a. $\left.2.54 \mathrm{mmol}\right)$ in diethyl ether $(70 \mathrm{ml})$ at $-70{ }^{\circ} \mathrm{C}$ over $15 \mathrm{~min}$. The resulting slurry was warmed to $-30^{\circ} \mathrm{C}$ and stirred for $3 \mathrm{~h}$ whereupon the precipitate of $\mathbf{8}$ was isolated by filtration and washed with cold diethyl ether $(2 \times$ $10 \mathrm{ml})(1.23 \mathrm{~g}, 90 \%) . \mathrm{mp} 18-20{ }^{\circ} \mathrm{C} \mathrm{dec}$.; ${ }^{1} \mathrm{H}$ NMR $(400 \mathrm{MHz}$, $\left.\mathrm{C}_{6} \mathrm{D}_{5} \mathrm{CD}_{3}, 270 \mathrm{~K}\right) \delta 1.02-2.05$ (unresolved $\mathrm{m}, 44 \mathrm{H}+4 \mathrm{H}, \mathrm{Cy}+$ $\mathrm{C}_{2} \mathrm{H}_{4}$ ), 5.76 ppm (br s, $\left.3 \mathrm{H}, \mathrm{InH}_{3}\right) ;{ }^{13} \mathrm{C} \mathrm{NMR}(100.6 \mathrm{MHz}$, $\left.\mathrm{C}_{6} \mathrm{D}_{5} \mathrm{CD}_{3}, 270 \mathrm{~K}\right) \delta 21.3\left(\mathrm{~s}, \mathrm{C}_{2} \mathrm{H}_{4}\right), 28.0\left(\mathrm{~d}, \mathrm{CH},{ }^{1} J_{\mathrm{PC}} 23.1 \mathrm{~Hz}\right)$, $30.1\left(\mathrm{~s}, \mathrm{CH}_{2}\right), 31.3\left(\mathrm{~s}, \mathrm{CH}_{2}\right), 34.4\left(\mathrm{~d}, \mathrm{CH}_{2},{ }^{2} \mathrm{~J}_{\mathrm{PC}} 12.9 \mathrm{~Hz}\right) ;{ }^{31} \mathrm{P}$ NMR (121.5 MHz, $\left.\mathrm{C}_{6} \mathrm{D}_{5} \mathrm{CD}_{3}, 270 \mathrm{~K}\right) \delta 1.45(\mathrm{~s})$; MS APCI: $m / z(\%) 212$ [ $\left.\left\{\mathrm{Cy}_{2} \mathrm{PCH}_{2} \mathrm{CH}_{2} \mathrm{PCy}_{2}\right\} \mathrm{H}_{2}{ }^{+}, 100\right]$; IR (Nujol) $v / \mathrm{cm}^{-1}$ 1657 (s br, In-H str.).

[ $\left.\operatorname{InBr}_{3}\left(\mathbf{E t I B u}^{t}\right)\right]$ 9. EtIBut $(0.22 \mathrm{~g}, 0.80 \mathrm{mmol})$ in THF (20 ml) was added dropwise to a solution of $\operatorname{InBr}_{3}(0.29 \mathrm{~g}, 0.82 \mathrm{mmol})$ in THF $(30 \mathrm{ml})$ at $-50^{\circ} \mathrm{C}$ over $15 \mathrm{~min}$. The resulting slurry was warmed to room temperature and stirred overnight whereupon volatiles were removed in vacuo. The residue was extracted with dichloromethane $(50 \mathrm{ml})$, filtered and the filtrate concentrated to $c a .30 \mathrm{ml}$. Placement at $-30{ }^{\circ} \mathrm{C}$ overnight yielded colourless prisms of $9(0.21 \mathrm{~g}, 41 \%)$. mp $159{ }^{\circ} \mathrm{C} ;{ }^{1} \mathrm{H}$ NMR $(400 \mathrm{MHz}$, $\left.\mathrm{CD}_{2} \mathrm{Cl}_{2}, 300 \mathrm{~K}\right) \delta 1.61\left(\mathrm{~s}, 18 \mathrm{H}, \mathrm{Bu}^{\mathrm{t}}\right), 5.20\left(\mathrm{~s}, 4 \mathrm{H}, \mathrm{CH}_{2}\right), 7.20$ (s, $2 \mathrm{H}, \mathrm{CH}), 8.50(\mathrm{~s}, 2 \mathrm{H}, \mathrm{CH}) ;{ }^{13} \mathrm{C} \mathrm{NMR}\left(100.6 \mathrm{MHz}, \mathrm{CD}_{2} \mathrm{Cl}_{2}\right.$, $300 \mathrm{~K}) \delta 30.5\left(\mathrm{~s}, \mathrm{C}\left(\mathrm{CH}_{3}\right)_{3}\right), 47.2\left(\mathrm{~s}, \mathrm{CH}_{2}\right), 61.8\left(\mathrm{~s}, \mathrm{C}\left(\mathrm{CH}_{3}\right)_{3}\right)$, 118.9 (s, CH), 124.8 (s, CH); MS APCI: $m / z(\%) 138\left[\left\{\mathrm{H}_{2} \mathrm{EtI}-\right.\right.$ $\left.\left.\mathrm{Bu}^{\mathrm{t}}\right\}^{2+}, 100\right], 549$ [\{M - $\left.\left.\mathrm{Br}\right\}^{+}, 46\right]$; IR (Nujol) $v / \mathrm{cm}^{-1} 782$ (s), 1129 (s), 1289 (s), 1375 (s).

[TICl ${ }_{3}\left(\mathbf{E t I B u}^{\mathrm{t}}\right)$ ] 10. $\mathrm{EtIBu}^{\mathrm{t}}(0.28 \mathrm{~g}, 1.02 \mathrm{mmol})$ in THF $(30 \mathrm{ml})$ was added dropwise to a solution of $\mathrm{TlCl}_{3}(0.61 \mathrm{~g}$, $1.97 \mathrm{mmol})$ in THF $(30 \mathrm{ml})$ at $-50{ }^{\circ} \mathrm{C}$ over $15 \mathrm{~min}$. The resulting slurry was warmed to room temperature and stirred overnight whereupon the precipitate was isolated by filtration, washed with THF $(30 \mathrm{ml})$ and dried in vacuo to yield $\mathbf{1 0}$ as a colourless powder. $(0.55 \mathrm{~g}, 92 \%)$. mp $132{ }^{\circ} \mathrm{C} \mathrm{dec}$.; ${ }^{1} \mathrm{H}$ NMR $\left(400 \mathrm{MHz}, \mathrm{CD}_{2} \mathrm{Cl}_{2}, 300 \mathrm{~K}\right) \delta 1.58\left(\mathrm{~s}, 18 \mathrm{H}, \mathrm{Bu}^{\mathrm{t}}\right), 5.17(\mathrm{~s}, 4 \mathrm{H}$, $\left.\mathrm{CH}_{2}\right), 7.03$ (s, $\left.2 \mathrm{H}, \mathrm{CH}\right), 8.42(\mathrm{~s}, 2 \mathrm{H}, \mathrm{CH}) ; \mathrm{MS}$ APCI: $\mathrm{m} / \mathrm{z}(\%)$ $138\left[\left\{\mathrm{H}_{2} \mathrm{EtIBu}^{\mathrm{t}}\right\}^{2+}, 100\right], 310\left[\left\{\mathrm{EtIBu}^{\mathrm{t}} \mathrm{Cl}\right\}^{+}, 41\right], 550[\{\mathrm{M}-$ $\mathrm{Cl}^{+}$, 23]; IR (Nujol) $v / \mathrm{cm}^{-1} 817$ (m), 1207 (s), 1325 (m), 1555 (s); accurate mas FAB $m / z\left[\mathrm{M}+\mathrm{H}^{+}\right]$calc. 585.1045 , found 585.1045 .

[EtIBut $\left.{ }_{2}\right][\mathbf{C l}]_{2}$ 11. EtIBu ${ }^{\mathrm{t}}(0.20 \mathrm{~g}, 0.73 \mathrm{mmol})$ in diethyl ether $(20 \mathrm{ml})$ was added dropwise to a solution of $\mathrm{AlCl}_{3}(0.10 \mathrm{~g}$, $0.72 \mathrm{mmol})$ in diethyl ether $(30 \mathrm{ml})$ at $-78^{\circ} \mathrm{C}$ over $15 \mathrm{~min}$. The resulting pale yellow slurry was warmed to room temperature and stirred overnight whereupon the precipitate was isolated by filtration, washed with diethyl ether $(2 \times 5 \mathrm{ml})$ and extracted into $\mathrm{CH}_{2} \mathrm{Cl}_{2}(40 \mathrm{ml})$. Concentration of the extract and cooling to $-30{ }^{\circ} \mathrm{C}$ yielded colourless prisms of $11(0.09 \mathrm{~g}, 36 \%)$. mp $132{ }^{\circ} \mathrm{C}$ dec.; ${ }^{1} \mathrm{H}$ NMR (400 MHz, $\mathrm{D}_{6}$-dmso, $300 \mathrm{~K}$ ) $\delta 1.64$ (s, $\left.18 \mathrm{H}, \mathrm{Bu}^{\mathrm{t}}\right), 4.85\left(\mathrm{~s}, 4 \mathrm{H}, \mathrm{CH}_{2}\right), 7.81(\mathrm{~s}, 2 \mathrm{H}, \mathrm{CH}), 8.15(\mathrm{~s}, 2 \mathrm{H}, \mathrm{CH})$, 9.72 (s, $2 \mathrm{H}, \mathrm{NCHN}) ;{ }^{13} \mathrm{C}$ NMR $\left(100.6 \mathrm{MHz}, \mathrm{D}_{6}\right.$-dmso, $\left.300 \mathrm{~K}\right)$ $\delta 29.5\left(\mathrm{~s}, \mathrm{C}\left(\mathrm{CH}_{3}\right)_{3}\right), 45.6\left(\mathrm{~s}, \mathrm{CH}_{2}\right), 60.1\left(\mathrm{~s}, \mathrm{C}\left(\mathrm{CH}_{3}\right)_{3}\right), 120.1$ (s, CH), $123.2(\mathrm{~s}, \mathrm{CH}), 153.5$ (s, NCHN); IR (Nujol) $v / \mathrm{cm}^{-1}$ 1562(s), 1470(sh), 1372(s), 1255(s), 1106(s), 1014(s), 799(s).

\section{Structure determinations}

Crystals of 5, 7, 9 and $\mathbf{1 1}$ suitable for X-ray structure determination were mounted in silicone oil. Crystallographic measurements were made using a Nonius Kappa CCD diffractometer. The structures were solved by direct methods and refined on $F^{2}$ by full matrix least squares (SHELX-97) ${ }^{18}$ using all unique data. All non-hydrogen atoms are anisotropic with $\mathrm{H}$-atoms included in calculated positions (riding model), except the hydride ligands in $\mathbf{7}$ and all hydrogen atoms in $\mathbf{5}$ which were located from difference maps and refined isotropically. Two molecules of dichloromethane of solvation are included in the crystal lattice of 9 and one molecule of dichloromethane in the lattice of 11. Crystal data, details of data collections and refinements are given in Table 1. The molecular structures of the complexes are depicted in Figs. 1-4 and show ellipsoids at the $30 \%$ probability level.

CCDC reference numbers $177618-177621$

See http://www.rsc.org/suppdata/dt/b2/b200500j/ for crystallographic data in CIF or other electronic format.

\section{Acknowledgements}

We gratefully acknowledge financial support from EPSRC (studentships for M.L.C and postdoctoral fellowship for R.J.B). We thank the EPSRC Mass Spectrometry Service for the accurate mass measurement on compound $\mathbf{1 0}$.

\section{References}

1 W. A. Herrmann and C. Köcher, Angew. Chem., Int. Ed. Engl., 1997, 36, 2162 and references therein

2 e.g. (a) A. A. D. Tulloch, A. A. Danopolous, R. P. Tooze, S. M. Cafferkey, S. Kleinhenz and M. B. Hursthouse, Chem. Commun., 2000, 1247; (b) D. S. McGuinness and K. J. Cavell, Organometallics, 2000, 19, 741; (c) J. Huang and S. P. Nolan, J. Am. Chem. Soc., 1999, 121, 9889; $(d)$ W. A. Herrmann, M. Elison, J. Fischer, C. Kocher and G. R. J. Artus, Angew. Chem., Int. Ed. Engl., 1995, 34, 2371 and references therein.

3 (a) R. E. Douthwaite, M. L. H. Green, P. J. Silcock and P. T. Gomes, Organometallics, 2001, 20, 2611; (b) K. Öfele, W. A. Herrmann, D. Mihalios, M. Elison, E. Herdtweck, W. Scherer and J. Mink, J. Organomet. Chem., 1993, 459, 177 and references therein.

4 C. J. Carmalt and A. H. Cowley, Adv. Inorg. Chem., 2000, 50, 1.

5 S. J. Black, D. E. Hibbs, M. B. Hursthouse, C. Jones, K. M. A. Malik and N. A. Smithies, J. Chem. Soc., Dalton Trans., 1997, 4313.

6 C. D. Abernethy, M. L. Cole and C. Jones, Organometallics, 2000, 19, 4852 .

7 M. L. Cole, A. J. Davies and C. Jones, J. Chem. Soc., Dalton Trans., 2001, 2451.

8 (a) D. E. Hibbs, M. B. Hursthouse, C. Jones and N. A. Smithies, Chem. Commun., 1998, 869; (b) M. D. Francis, D. E. Hibbs, M. B. Hursthouse, C. Jones and N. A. Smithies, J. Chem. Soc., Dalton Trans., 1998, 3249

9 (a) M. L. Cole, D. E. Hibbs, C. Jones and N. A. Smithies, J. Chem. Soc., Dalton Trans., 2000, 545; (b) D. E. Hibbs, C. Jones and N. A. Smithies, Chem. Commun., 1999, 185.

10 R. E. Douthwaite, D. Haüssinger, M. L. H. Green, P. J. Silcock, P. T. Gomes and A. M. Martins, Organometallics, 1999, 18, 4584.

11 (a) M. G. Gardiner and C. L. Raston, Coord. Chem. Rev., 1997, 166, 1; (b) C. Jones, G. A. Koutsantonis and C. L. Raston, Polyhedron, 1993, 12, 1829 and references therein.

12 J. L. Atwood, K. D. Robinson, C. Jones and C. L. Raston, J. Chem. Soc., Chem. Commun., 1991, 1697.

13 Value obtained from a survey of the Cambridge Crystallographic Database.

14 C. Jones, Chem. Commun., 2001, 2293.

15 D. E. Hibbs, M. B. Hursthouse, C. Jones and N. A. Smithies, Main Group Chem., 1998, 2, 293.

16 J. K. Ruff and M. F. Hawthorne, J. Am. Chem. Soc., 1960, 82, 2141.

17 D. F. Shriver and A. E. Shirk, Inorg. Synth., 1977, 17, 45.

18 G. M. Sheldrick, SHELXL-97, University of Göttingen, 1997. 